\title{
A rights-based approach to environmental protection: The Zimbabwean experience
}

\author{
Tinashe Madebwe* \\ Lecturer of law, Department of Public Law, Midlands State University, Gweru, \\ Zimbabwe
}

\begin{abstract}
Summary
Stemming from the common law, international law and statute, Zimbabwean law has always recognised the prominent role that environmental rights should play in the environmental regulatory framework. In theory, this was based on recognition of the fact that the provision of such rights, and their full enjoyment by citizens, would allow Zimbabweans the opportunity to live in a clean and healthy environment. In addition, through exercising these rights, citizens could directly enforce environmental laws. In practice, however, it appears that deficiencies in the environmental regulatory framework at the institutional level precluded Zimbabweans from fully exercising or enjoying their environmental rights. It was against this backdrop that Zimbabwe in 2013 enacted a new Constitution which entrenched environmental rights in the Declaration of Rights. This was a welcome development which aligned Zimbabwean law with developments across various other jurisdictions which have accorded environmental rights constitutional importance. Importantly, and in light of the seeming deficiencies in the environmental law regulatory framework at the institutional level, which manifested in Zimbabweans not fully exercising, or enjoying, their environmental rights prior to the inception of the Constitution, this article explores whether the inclusion of environmental rights in Zimbabwe's Constitution has been accompanied by sufficient efforts to put in place institutional measures to ensure that citizens exercise and enjoy their rights.
\end{abstract}

Key words: environmental rights; education; litigation; institutional measures

* $\quad$ LLB LLM (Rhodes), PhD (Strathclyde); tinzel4@yahoo.com 


\section{Introduction}

The value of a rights-based approach to pursuing environmental protection has often inspired debate and disagreement for at least three reasons. ${ }^{1}$ First, the argument has been made that a rights-based approach is problematic to the extent that rights are, most commonly, bestowed upon humans, with humans having the right of action when their rights are infringed. The difficulty this poses is that environmental harm can occur which does not affect humans. ${ }^{2}$ Alternatively, harm might occur which affects humans. However, such harm may be unknown to them, or it may not directly affect them in a manner they appreciate. As such, they may simply not be moved to act in protection of the environment on the basis of their rights. ${ }^{3}$ Furthermore, it has also been argued that this approach is of limited use for the protection of aspects of the environment, such as particular species which are of 'no present and potential interest to humankind'. ${ }^{4}$

Second, while it is apparent that procedural rights, such as access to information, access to justice and participatory rights, allow rights to be used to prevent environmental harm from occurring, it has often been argued that the rights-based approach cannot yield the

1 D Shelton 'Human rights, environmental rights and the right to the environment' (1991) 28 Stanford Journal of International Law 103; G Handl 'Human rights and the protection of the environment: A mildly revisionist view' in AC Trindade (ed) Human rights, sustainable development and the environment (1992) 117; AE Boyle \& MR Anderson (eds) Human rights approaches to environmental protection (1996) ch 2-4; F Francioni 'International human rights in an environmental horizon' (2010) 21 European Journal of International Law 4144 54-55; AE Boyle 'Human rights or environmental rights? A reassessment' (2007) 1-2 http://www.law.ed. ac.uk/includes/remote_people_profile/remote_staff_profile?sq_content_src $=\% 2 B X$ JsPWhOdHAIMOEIMkYIMkZ3d3cyLmxhdy5IZC5hYy51 ayUyRmZ̈pbGVfZG93bmxvY WQIMkZwdW|saWNhdGlvbnMIMkYwXzEyMjFfaHVtYW5yaWdodHNvcmVudmlyb 25tZW50YWxyaWdodHNhcmVhc3Nlcy5wZGYmYWxsPTE\%3D (accessed 29 May 2015).

2 See the enlightening discussion on anthropocentricism and ecocentrism, albeit with reference to the principle of intergenerational equity in D Tladi 'Of course for humans: A contextual defence of intergenerational equity' (2002) 9 South African Journal of Environmental Law and Policy 177 182-185. See also LA Feris \& D Tladi 'Environmental rights' in D Brand \& C Heyns (eds) Socio-economic rights in South Africa (2005) 249 252, who note that 'ecocentrists reject anthropocentrism (and by necessity any human rights approach) as flawed, because under such approaches the environment is protected, not because it has intrinsic value, but only for the sake of man'.

3 AS Timoshenko 'Ecological security: Global change paradigm' (1990) 1 Colorado Journal of International Environmental Law and Policy 127-131; M Dixon Textbook on international law (2003) 466; E Louka International environmental law: Fairness, effectiveness and world order (2006) 16-17; Boyle (n 1 above) 1-3; D Bodansky et al 'International environmental law: Mapping the field' in D Bodansky et al The Oxford handbook of international environmental law (2007) 15-16; P Birnie et al International law and the environment (2009) 7.

$4 \quad$ D Tladi 'Strong sustainable development, weak sustainable development and the earth charter: Towards a more nuanced framework of analysis' (2004) 11 South African Journal of Environmental Law and Policy 22-24. See also Tladi (n 2 above) 182-185. 
sort of environmental protection necessary to protect the environment because it predominantly is backward-looking and reactive rather than preventative, a more preferable approach. ${ }^{5}$ The rationale here seems to stem from the fact that, for preventative action to be taken by the public using their rights, a concerned public typically needs to be proactive in guarding against environmental harm. Unfortunately, experience has shown that, in the absence of a catastrophic event, the public are simply not as diligent as they could be with respect to environmental protection. ${ }^{6}$ Consequently, rights are most typically exercised once offending activities have been initiated or concluded.

Third, and perhaps most importantly for present purposes, a rightsbased approach works best where rights holders have the capacity to exercise rights and enjoy the benefits these rights bestow on them. Such capacity can assume the form of citizens being educated on their rights and how to exercise them. Indeed, in some cases, effective education might even motivate citizens to familiarise themselves with the state of the environment in which they live and, thus, rely on their procedural rights to access information which may put them in a position to undertake action which might pre-empt the occurrence of environmental harm. However, it is also important to consider that, even where rights holders may be educated on their environmental rights, bringing, or threatening to bring, litigation as part of exercising rights can be expensive. ${ }^{7}$ As such, it has long been recognised that the value of a rights-based approach is also dependent on rights holders having the capacity to act in protection of their rights through having sufficient resources to bring and sustain litigation in the protection of these rights.

Despite all this, there is some agreement that a rights-based approach is a useful complement to any environmental law regulatory framework. In a complementary role to traditional regulatory measures, this approach can empower the public to enforce laws through bringing, or threatening to bring, litigation and this may even serve a deterrent function. ${ }^{8}$ Importantly, however, where such approach is adopted, realising the value it can bring to a state's

5 Feris \& Tladi (n 2 above) 251; T Crossen 'Multilateral environmental agreements and the compliance continuum' (2004) 16 The Georgetown International Environmental Law Review 11; M Mason 'Citizenship entitlements beyond borders? Identifying mechanisms of access and redress for affected publics in international environmental law' (2006) 12 Global Governance 283288.

6 BK Bucholtz 'Coase and the control of transboundary pollution: The sale of hydroelectricity under the United States-Canada free trade agreement of $1988^{\prime}$ (1991) 18 Boston College Environmental Affairs Law Review 279; G Handl 'Environmental security and global change: The challenge to international law' (1990) 1 Yearbook of International Environmental Law 3 4; CD Stone 'Defending the global commons' in P Sands Greening international law (1993) 34.

7 C McGrath 'Flying foxes, dams and whales: Using federal environmental laws in the public interest' (2008) 25 Environmental and Planning Law Journal 324.

8 McGrath (n 7 above) 335-340; AE Boyle 'Human rights and the environment: Where next?' (2012) 23 The European Journal of International Law 613-614. 
regulatory framework is dependent upon the state putting in place institutional measures to ensure that the public are educated on the existence of environmental rights and the manner in which to exercise them so that they may derive the benefits these rights bestow. In addition, realising the value of a turn to rights is also dependent on a state putting in place institutional measures to assist litigants, and potential litigants, in bringing rights-based matters to court.

This dynamic between the mere provision of environmental rights in a state's legal framework and the provision of institutional measures to educate citizens on the existence of these rights and to capacitate them to rely on litigation, or the threat thereof, so that they may exercise their environmental rights and enjoy the benefits they bestow, has recently become particularly interesting in the Zimbabwean context, for two reasons.

First, Zimbabwean law has traditionally recognised the important role that environmental rights play as a complement to environmental protection regulatory efforts. It was hardly surprising, therefore, that in 2013 environmental rights found their way into section 73 of the 2013 Zimbabwean Constitution's Declaration of Rights. ${ }^{9}$

Second, despite Zimbabwean law's long-standing recognition of the role that environmental rights play in regulating environmental protection efforts, Zimbabweans have, for the longest time, acted in a manner which suggests that they may either be unaware of the existence of such environmental rights, or be unable to fully exercise them for their benefit. To illustrate, there has been very little rightsbased litigation brought to the courts. Separately, despite the positive obligation environmental rights place on the state to secure a clean environment for citizens, in Zimbabwe, as in various other developing states, the state has prioritised the pursuit of development often to the detriment of the pursuit of environmental protection objectives. Importantly, such choices on the part of the state have met with limited resistance from citizens, through exercising their rights to protect the environment on their own behalf, or through calling on the state to honour its positive obligation to ensure that citizens live in a clean environment. This suggests that there is a certain passivity on the part of Zimbabwean citizens with respect to exercising their environmental rights.

Certainly, the passivity that Zimbabweans have shown with respect to exercising their environmental rights to secure a clean environment on their own behalf, or through insisting on the state honouring its positive obligation to ensure that they live in a clean environment, could be due to citizens being willing to subjugate environmental protection objectives so that economic development may be pursued. However, the substantial dearth of rights-based litigation, or rightsbased challenges to the state's policy choices, suggests that the more

9 Constitution of Zimbabwe Amendment (20) Act 2013. 
likely reason for citizens' passivity in this regard is that they are unaware of the existence of environmental rights. Even where they may be aware of these rights, they may lack the financial capacity to bring rights-based actions in protection of their environmental rights or the environment generally. As such, it is reasonable to arrive at the conclusion that, while Zimbabwean law has recognised the important role that environmental rights play in the environmental regulatory framework, in practice little has been done by the state at the institutional level to secure citizens' actual exercise and enjoyment of environmental rights and the benefits they bestow.

Considering that there has been the welcome turn to entrenching environmental rights in the Declaration of Rights of the Constitution, it has become increasingly important to assess, as this article does, the value that these rights will bring to the environmental regulatory framework in light of the past., and negative experience with such rights. In pursuance of this objective, the article is presented in two parts. First, in light of environmental rights having always formed part of Zimbabwean law, but were not fully exercised, the article commences with a discussion of prominent sources of environmental rights prior to the 2013 Constitution. As part of this discussion, I will analyse why it is that citizens did not seemingly exercise these rights and, as such, enjoy the benefits that these rights bestowed upon them. Following from this, and in the second section, I explore the extent to which measures have been put in place to facilitate the exercise of environmental rights in the 2013 Constitution, bearing in mind the history of environmental rights in Zimbabwean law.

\section{Environmental rights prior to the Constitution}

It is interesting to note that there has always been a dearth of environmental law cases in Zimbabwe. Based on the preceding discussion, a preliminary assessment would suggest that this is likely due to a lack of education on environmental rights, how to exercise them and, as such, how to enjoy the benefits they bestowed. The dearth of cases may also have been attributable to a lack of capacity on the part of citizens to bring rights-based litigation. Importantly, however, the absence of such cases does not discount the fact that, in tracing the development of Zimbabwean law from a chronological perspective, it is quite apparent that a rights-based approach to environmental protection has always formed part of Zimbabwean 
law. ${ }^{10}$ Indeed, environmental rights have been provided for in three distinct ways over the course of the country's legal history.

\subsection{Common law}

Zimbabwe embraced Roman-Dutch law as its basic law since it attained independence. This was explicitly provided for in the 1979 Constitution which, in section 89, provided that '[t]he law to be administered by the Supreme Court, the High Court and by any courts in Zimbabwe subordinate to the High Court shall be the law in force in the Colony of the Cape of Good Hope on 10th June, 1891'.11 Importantly, this has meant that environmental rights have always existed as part of the common law of nuisance, and of delict.

Thus, rooted in the law of delict, Zimbabwean law has always recognised that where an act of pollution has caused personal injury or damage to someone's property, the victim can use the delictual remedy of Aquilian action. ${ }^{12}$ Further, the law recognises a general duty of care, akin to the good neighbourliness (sic tuo utere) principle in international law. ${ }^{13}$ In terms of this duty, a person would be regarded as having breached this duty, and thus a right, where that person failed to foresee and guard against harm which the reasonable person would have foreseen and guarded against. ${ }^{14}$ Importantly, the law of delict established the existence of environmental rights to the extent that citizens could reasonably expect to live in a clean environment. Where the negligent acts of another party, rooted in a failure to honour the duty of care, compromised this and led to damages occurring, the harmed party had a right of action to pursue redress.

Similarly, environmental rights could be inferred to exist from the law of nuisance. To this end, a private nuisance was taken to occur

10 Chronology is important to tracing the development of the law here. On the one hand, it will form the basis on which to assess the impact the Constitution is likely to have. On the other, the emphasis on chronological development accounts for the ensuing discussion being structured in a common law, international law, and then statute law way, rather than the more traditional, and established, international law, statute, common law progression.

11 Schedule to the Zimbabwe Constitution Order 1979 (SI 1979/1600 of the United Kingdom). The 2013 Constitution does not carry a similar provision. However, it does make reference to 'the common law' in various provisions. It is reasonable therefore to assume that this is the same common law which had been in effect since independence, and the 1979 Constitution.

12 The application of this is quite like that in South African law. See M Kidd Environmental law (2008) 133-134.

13 On the Zimbabwean law of delict, generally, see $G$ Feltoe $A$ guide to the Zimbabwean law of delict (2006). On the good neighbourliness principle, see Principles 2, 18, and 19 of the Rio Declaration on Environment and Development, A/CONF.151/26; HA Strydom 'The legal principles relating to climate change' http://www.eolss.net/sample-chapters/c14/E1-36-10-00.pdf (accessed 29 May 2015). Also see $S$ Sucharitkul 'The principles of good-neighbourliness in international law' (1996) http://digitalcommons.law.ggu.edu/cgi/viewcontent.cgi ?article $=1559 \&$ context=pubs (accessed 29 May 2015).

14 Feltoe (n 13 above) 26. 
when a neighbour interfered with an owner's use and enjoyment of his or her land. ${ }^{15}$ This body of the common law allowed for action to be brought against a party who caused a nuisance which resulted in patrimonial loss, or in the instance of a continuing nuisance. ${ }^{16}$ Importantly, the law of nuisance established the right to a clean environment, and one which was not harmful to health and wellbeing, to the extent that it created a right of action for a party whose right had been infringed to pursue redress.

There were various advantages which attached to the recognition of these common law-based rights as part of the environmental regulatory framework. Most notably, there was little need to educate the public extensively on the existence of such rights at the institutional level. Instead, the delictual basis of the rights meant that citizens were likely aware of the right of action created where they suffered harm, as part of their existing knowledge of the law of delict and nuisance. Such knowledge would typically be motivated by financial self-interest, as citizens would be aware of the fact that violations of their rights would lead to the payment of compensation where they could establish that their rights had been infringed. The promise of compensation also meant that citizens were motivated to act in protection of their rights and, by extension, the environment, whenever environmentally deleterious activities which caused them harm occurred. ${ }^{17}$ Closely aligned with this, the threat of rights-based actions, and the possibility of paying compensation to rights holders, were effective deterrents to those acting in a potentially-harmful manner. For instance, the fact that citizens could act in protection of the environment placed a measurable positive obligation on the state to ensure that citizens enjoyed the right to live in a clean environment.

Despite these advantages, however, the deficiency with such an approach, one which attaches to rights-based actions generally, was that such an approach typically depended on citizens' capacity to pursue redress based on these rights. ${ }^{18}$ In the Zimbabwean context, the prohibitive costs attached to pursuing litigation meant that this was not an avenue which many citizens could exploit. ${ }^{19}$ To compound matters, there was little done at the institutional level to

15 A similar position to the one in South Africa; see Kidd (n 12 above) 130-133.

16 Kidd (n 12 above) 76

17 See, however, Kidd (n 12 above) 134.

18 On willing and able plaintiffs, see BJ Preston 'Environmental public interest litigation: conditions for success' (2013) http://www.lec.lawlink.nsw.gov.au/ag dbasev7wr/_assets/lec/m420301/721754/preston_environmental\%20public\%20 interest\%20litigation.pdf (accessed 29 May 2015).

19 See T Murombo 'Balancing interests through framework legislation in Zimbabwe' in M Faure \& W du Plessis (eds) The balancing of interests in environmental law in Africa (2011) 557 576. Also, it is worth noting that Zimbabwe is a typical example of a jurisdiction in which environmental offences are regarded as mala prohibita (prohibited acts, often by statute) and not mala in se (criminal acts, often seen as morally reprehensible). For a discussion of the two, see $S$ Bell \& D McGillivray 
assist litigants bringing such rights-based claims. Possibly this was because, being rooted in the common law, such actions were seen as private law matters. As such, there was an expectation on the part of the state that, where rights were infringed, harmed citizens would pursue individual redress. In turn, once such compensation was secured, the state would not direct the harmed party with respect to how to use the compensation award. Thus, it was conceivable that once compensation awards were secured, they would not go toward restoring the environment to its former state for the public benefit. In this context, there was limited state motivation to assist litigants in meeting the costs of such litigation in order for them to bring actions which could reasonably be regarded as being for citizens' personal gain.

\subsection{International law}

Zimbabwe ratified the African Charter on Human and Peoples' Rights (African Charter) in $1986 .{ }^{20}$ Article 24 of the Charter, to which the country remains party, provides that '[a]ll peoples shall have the right to a general satisfactory environment favourable to their development'. In addition, article 25 of the Charter provides:

States parties to the present Charter shall have the duty to promote and ensure through teaching, education and publication, the respect of the rights and freedoms contained in the present Charter and to see to it that these freedoms and rights as well as corresponding obligations and duties are understood.

Of note, Zimbabwe has always been a dualist state. ${ }^{21}$ As such, ratification of the African Charter had to be accompanied by the enactment of enabling legislation giving effect to the Charter, or rights in the Charter. ${ }^{22}$ In theory, once this was done, it would lead to the imposition of an expansive positive obligation on the state to

Environmental law (2008) 259. In addition, Zimbabweans are generally not litigious people. Add to that the costs attached to bringing cases and the result was that no cases were brought to the courts in which these environmental rights were exercised.

20 Organisation of African Unity (OAU) African Charter on Human and Peoples' Rights ('Banjul Charter') 27 June 1981, CAB/LEG/67/3 rev 5, 21 ILM 58 (1982) http://www.refworld.org/docid/3ae6b3630.html (accessed 29 May 2015), reprinted in C Heyns \& M Killander Compendium of key human rights documents of the African Union (2013) 29.

21 This tradition was maintained in sec 34 of the 2013 Constitution which provides that ' $[\mathrm{t}] \mathrm{h}$ e state must ensure that all international conventions, treaties and agreements to which Zimbabwe is a party are incorporated into domestic law'.

22 See eg the 2 nd Report by the country to the Commission detailing legislative measures taken by the state to ensure compliance with provisions in the Charter, http://www.achpr.org/files/sessions/21st/state-reports/2nd,3rd-1992-1996/state rep23_zimbabwe_1996_eng.pdf (accessed 29 May 2015). 
ensure that citizens lived in a clean environment. ${ }^{23}$ This would be a significant progression in two respects. First, in terms of article 24 of the African Charter, domestication would place the state under an obligation to secure a clean environment for citizens. Second, domestication of article 25 of the African Charter would also make it reasonable to expect the state to put in place measures to educate the citizenry on the implications of the rights in the Charter and, possibly, institutional measures to assist citizens bringing environmental rightsbased litigation in getting to court.

Importantly, little was done to domesticate environmental rights provided for in the African Charter. ${ }^{24}$ Added to this, little was done to educate the citizenry on the value of environmental rights contained in the Charter. If anything, the state played a role in diminishing the public's perception of environmental rights through consistently reneging on its duty to secure a clean environment for citizens. This was seemingly based on the fact that 'what constituted a decent environment was, and remains, a value judgment, on which reasonable people differed' ${ }^{25}$ As such, the state used this 'loophole' as the basis for arguing that, based on various considerations, it was more reasonable to prioritise socio-economic development goals to better the nation's circumstances than to secure a clean environment for citizens. There was also little done to assist litigants in bringing environmental rights-based claims before the court.

Presumably, there were at least two reasons to account for all this. First, the failure to effectively educate the public may have been rooted in the fact that such a drive to educate the public was seen as unnecessary considering that the African Charter carried rights which were widely known as part of the existing national Constitution and, in some instances, these rights had acquired an erga omnes quality. ${ }^{26}$ Second, the fact that the environmental rights in the African Charter are peoples' rights and, as such, would most commonly be exercised against the state, meant that the state would have been reluctant to educate citizens on the rights as this would empower them to bring

23 Specific actions required of states in fulfilment of art 24 include 'ordering or at least permitting independent scientific monitoring of threatened environments, requiring and publicising environmental and social impact studies prior to any major industrial development, undertaking appropriate monitoring and providing information to those communities exposed to hazardous materials and activities and providing meaningful opportunities for individuals to be heard and to participate in the development decisions affecting their communities'. See Boyle (n 1 above) 3-5; Francioni (n 1 above) 52.

24 See, to this end, the 1st and 2nd Reports by the country to the Commission detailing activities to give effect to the Charter, which made no reference to efforts to give effect to art 24 of the Charter. For the 1 st Report, see http://www. achpr. org/files/sessions/12th/state-reports/1st-1986-1991/staterep1_zimbabwe 1992 eng.pdf. (accessed 29 May 2015). For the 2nd Report, see http://www. achpr.org/ files/sessions/21st/state-reports/2nd,3rd-1992-1996/staterep23_zimbabwe_1996_ eng.pdf. (accessed 29 May 2015).

25 Boyle (n 8 above) 626-627.

26 As above. 
actions against it. The state would have been equally reluctant to financially assist litigants who would possibly bring litigation against it.

Regardless, the important point to note is that this culminated in a situation in which an unaware public hardly acted to force the state to honour its positive obligations. In addition, it is not difficult to see how, in this context, the state did not feel compelled to put in place institutional measures to assist litigants in bringing rights-based litigation to court when their rights were infringed.

\subsection{Statute}

Perhaps the fundamental starting point when considering the provision of environmental rights in Zimbabwean statute law is to note that, prior to the 2013 Constitution, Zimbabwe already had a Constitution which carried various fundamental rights. ${ }^{27}$ Importantly, while this is not an avenue that Zimbabweans utilised in the pre-2013 constitutional era, it is reasonable to contend that there was statutory provision for environmental rights in the 1979 Constitution through the provision of a comprehensive Declaration of Rights in chapter III, to the extent that the Declaration incorporated a right to life in section 12 .

This contention is rooted in the observation that, in other jurisdictions, a similar right to life has been interpreted expansively, so as to recognise environmental rights. ${ }^{28}$ The logic applied has been that, in some instances, the full enjoyment of the right to life is dependent upon rights holders living in a clean environment which does not pose a threat to their right to life. ${ }^{29}$ As such, the right to life creates a positive obligation on the state and other citizens not to expose rights holders to an environment which is potentially harmful to their enjoyment of this right. ${ }^{30} \mathrm{~A}$ similar approach has been taken to interpreting other rights, such as the rights to health, privacy and property, as has been done in other jurisdictions. ${ }^{31}$

Quite separately to this, however, more explicit recognition of environmental rights as part of Zimbabwean statute law was achieved with the coming into effect of the Environmental Management Act in $2007 .{ }^{32}$ The Act remains the leading statutory instrument on Zimbabwean environmental law and laws dealing with natural

27 Schedule to the Zimbabwe Constitution Order 1979 (SI 1979/1600 of the United Kingdom).

28 See Feris \& Tladi ( 2 above) 251, who note that at international law, it may be the case that specific environmental rights are not recognised. However, the potential for protecting the environment under already-existing and recognised rights, such as the rights to life, health and dignity has been recognised. Also see Feris \& Tladi (n 2 above) 256.

29 Öneryildiz v Turkey (2004) ECtHR 20.

30 Boyle (n 1 above) 5.

31 Francioni (n 1 above) 43-44; Maya Indigenous Community of the Toledo District $v$ Belize IAHCR (2004) Doc 5 Rev 1.

32 Environmental Management Act [Chapter 20:27]. 
resources. To this end, section 3(2) of the Act provides that '[i]f any other law is in conflict or inconsistent with this Act, this Act shall prevail'. ${ }^{33}$ Importantly for present purposes, section 4(1)(a) of the Act provides that '[e]very person shall have a right to a clean environment that is not harmful to health'. In addition, section $4(1)(b)$ of the Act provides:

Every person shall have a right to -

(b) access to environmental information, and protect the environment for the benefit of present and future generations and to participate in the implementation of the promulgation of reasonable legislative policy and other measures that -

(i) prevent pollution and environmental degradation; and

(ii) secure ecologically sustainable management and use of natural resources while promoting justifiable economic and social development.

This aligned Zimbabwean law with various international conventions.

Despite this, and as had been the case following Zimbabwe's ratification of the African Charter, little was done to capacitate citizens to exercise the rights enshrined in section 4 of the Environmental Management Act. To this end, there were no educational drives intended to enlighten citizens on how to exercise their rights so that they could derive the benefits these rights bestowed on them. In addition, little was done to put in place measures to financially assist litigants in bringing, or threatening to bring, litigation in protection of their rights. It is hardly surprising that there were no cases brought to the courts based on these rights. Indeed, making a similar point, Murombo noted that there was provision for participatory rights in Zimbabwean law. However: ${ }^{34}$

Several constraints limit the exercise of these rights to those few who have the means to participate and the knowledge to follow legislative and planning processes. Hollow provisions on access to information are pointless in a society with low literacy rates and with other laws that make access to information near impossible. Similarly, access to courts when legal fees are beyond the reach of many and the processes mystified in archaic legalisms becomes a meaningless right.

33 The entry into force of the 2013 Constitution which, in $\sec 2$, provides that it is the supreme law of Zimbabwe and any law, practice, custom or conduct inconsistent with it is invalid to the extent of the inconsistency', has established the 2013 Constitution as a superior law generally. However, the Environmental Management Act remains the leading law with respect to environmental protection and laws dealing with natural resources. See Murombo (n 19 above) 567.

34 Murombo (n 19 above) 576 


\section{Environmental rights after the Constitution}

The preceding discussion highlights that, stemming from the common law, international law and statute, Zimbabwean law has always recognised the prominent role that environmental rights should play in the environmental regulatory framework. Despite this, an absence of adequate institutional measures to educate citizens on these rights and to assist litigants in bringing rights-based claims to court culminated in a situation in which citizens hardly exercised or enjoyed the benefits such rights bestowed. The cumulative effect of this was that, while environmental rights formed a visible part of the environmental regulatory framework, they were hardly used as a complement to other regulatory efforts.

It is against this backdrop that, in 2013, the country enacted a new Constitution which entrenched environmental rights in section 73 of the Declaration of Rights. Section 73(1)(a) provides that 'every person has the right to an environment that is not harmful to their health or well-being', and section 73(1)(b) that

[e]very person has the right to have the environment protected for the benefit of present and future generations, through reasonable legislative and other measures that prevent pollution, promote conservation, and secure ecologically sustainable development and use of natural resources while promoting economic and social development.

In addition to this, section 62 of the Constitution grants every citizen the right of access to information. To complement this, section 85 of the Constitution provides access to court for any individual whose rights are infringed. Read with section 73, these rights ensure that necessary substantive and procedural rights for enjoying the right to a clean environment are available to all citizens. ${ }^{35}$

Entrenching environmental rights in the Constitution in this manner is a notable development to the extent that it suffices as recognition of the prominent role that such rights play as part of the environmental regulatory framework. Despite this, it is clear by now that, if such rights are to serve as a useful complement to environmental protection efforts, they should be accompanied by institutional measures to educate citizens on the rights and the extent to which they can exercise them and enjoy the benefits these rights bestow. In addition, there is a need for institutional measures to assist litigants in bearing the costs of litigation.

35 See Feris \& Tladi (n 2 above) 263, who note that 'environmental laws should provide not only for the substantive aspects of environmental protection, but also for related procedural safeguards such as standing, access to information and just administrative action'. 


\subsection{Education}

Educating the public on environmental rights is particularly important because it is often the case that violators, and potential violators, of these rights are very knowledgeable about the content of these rights. As such, educating the public on these rights becomes an important way of empowering them to exercise them against potential, and actual, violators. ${ }^{36}$ Importantly, as McGrath appositely notes, albeit with reference to public interest litigation, education is important because: 37

Knowledge ... is crucial for effective ... litigation to protect the environment. The environmental legal system is often complex, convoluted and illogically structured with multiple legislative schemes and government administrators. Complex issues of law and fact commonly arise with which ordinary members of the community are unfamiliar.

Against this backdrop, it becomes apparent that one of the major failures under the pre-2013 Constitution, the Zimbabwean environmental rights regulatory framework, which compromised citizens' exercise and enjoyment of their environmental rights, was the fact that citizens were not effectively educated on the existence of such rights. In addition, little was done to educate citizens on the importance attaching to environmental rights through concerted efforts by the state to meet its positive obligation to ensure citizens lived in a clean environment. ${ }^{38}$ This was true despite the fact that various sources of environmental rights consistently recognised the existence of a positive obligation on the state to ensure that citizens lived in a clean and healthy environment. For instance, there has always been a positive obligation on the state not to interfere with citizens' enjoyment of their rights to live in a clean environment inferred from fundamental rights such as the right to life. ${ }^{39}$ In addition, it was accepted in terms of the common law that an injured party could take the state to task where their rights were threatened or infringed by state action. A similar positive obligation to ensure that citizens lived in a clean environment suitable for their development was also apparent from article 24 of the African Charter, which Zimbabwe ratified in $1986 .{ }^{40}$ Separately, the existence of this positive obligation could be inferred from the environmental right as enshrined in section 4 of Zimbabwe's Environmental Management Act.

Importantly, a lack of education on the role that environmental rights played in allowing citizens to act to protect the environment on their own behalf when the state did not do so, and the state

36 S Leckie \& A Gallagher Economic, social and cultural rights: A legal resource guide (2006).

37 McGrath (n 7 above) 334.

38 Boyle (n 8 above) 626-627.

39 Boyle (n 1 above) 5; Francioni (n 1 above) 43-44.

40 Boyle (n 1 above) 3-5; Francioni (n 1 above) 52. 
frequently reneging on its positive obligation to secure a clean environment for citizens in terms of these rights, culminated in a situation in which environmentally-deleterious activities were simply not taken by the public as violations of environmental rights. The impact of this was twofold. First, citizens did not see violations of environmental rights as meriting the commencement of rights-based actions in the protection of their environmental rights. Second, citizens' passivity with respect to exercising environmental rights and the consequent lack of public participation with respect to environmental protection created a situation in which the state did not feel compelled to put in place measures to secure a clean environment for citizens.

In light of this history, it was reasonable to expect that, following the entrenchment of environmental rights in section 73 of the Constitution, a concerted effort would have been made to educate citizens on the existence of these rights so that they would understand them and how to use them. Certainly, it merits consideration that the manner in which Zimbabwe transitioned to a new constitutional dispensation meant that the existence of an environmental right, in theory at least, received extensively more publicity than it had before. This was largely due to the fact that the acceptance of the Constitution into law was based on a 'yes' vote in a referendum held in 2013.41 Importantly, in the build-up to the referendum, most Zimbabweans got familiar with various aspects of the Constitution and, in particular, the Declaration of Rights. In addition, it is also worth noting that following this process, a directive on the state to educate citizens on the Constitution through different avenues was included in section 7 of the Constitution. ${ }^{42}$ In addition, a Human Rights Commission was created and tasked with, inter alia, the promotion of awareness of and respect for human rights and freedoms at all levels of society, the promotion of the protection, development and attainment of human rights, and conducting research into issues relating to human rights and freedoms and social justice. ${ }^{43}$

Of note, however, anecdotal evidence suggests that, while the collection of fundamental rights enjoyed extensive publicity during the referendum process, little was done to educate citizens on how to use these rights and make them work for them. Indeed, it can reasonably be argued that, presently, the public seem to be as knowledgeable about environmental rights now as they were prior to the coming into effect of the Constitution. This is despite the fact that it was quite clear, in light of Zimbabwe's history, that the education of

41 The Referendum was held on 16 and 17 March 2013.

42 Avenues include (a) translation of the document into all officially-recognised languages and wide dissemination; (b) teaching of the Constitution across all levels; and (c) encouragement of all persons and organisations to disseminate awareness and knowledge of the Constitution throughout society.

43 See sec 243 of the 2013 Constitution. 
citizens on the importance of environmental rights needed to be enhanced and, as such, needed to be an issue that received attention in the Constitution. Similarly, while the turn to a Human Rights Commission is laudable, the Commission is tasked with supporting and promoting all human rights. This is plausible in theory, but the Zimbabwean experience suggests that it is likely that the focus of the Commission will be drawn to the more traditionally-established rights, such as the right to life, privacy, expression and perhaps minority rights, which have increasingly become a prominent feature of rights discourse in Zimbabwe. There is unlikely to be much attention paid to environmental rights. Indeed, it is telling that while the functions of the Commission are couched in broad and general terms, the Commission is specifically directed to 'visit and inspect prisons, places of detention, refugee camps' and 'places where mentally-disordered or intellectually handicapped persons are detained' ${ }^{44}$

A more preferable approach therefore, would have seen guidance drawn from the Indian approach, where article 48A of the country's Constitution provides that ' $[\mathrm{t}] \mathrm{he}$ state shall endeavour to protect and improve the environment and to safeguard the forests and wild life of the country'. ${ }^{45}$ Instead, what has emerged is a generic and qualified obligation on the state to take 'reasonable legislative and other measures, within the limits of the resources available to it, to achieve progressive realisation of the rights' in section 73 of the Constitution. Such a qualified and generic clause is simply not enough considering that, in the Zimbabwean context, significantly more needs to be done by way of directing the legislature to craft legislation and measures to ensure citizens enjoyed their rights. In addition, the obligation on the state enshrined in section 73 is too remote, considering that the state has traditionally reneged on its positive obligation to secure a clean environment for citizens. As such, it is unlikely that the qualified positive obligation on the state to secure a clean environment for citizens in section 73 will yield any real behavioural change on the part of the state. A more likely scenario is that the state will rely on the disclaimer in section 73 as justification for reneging on its positive obligations to secure a clean environment for citizens. In light of this, a markedly more assertive obligation on the state to prevent ecological degradation and promote conservation needed to be drafted into the Constitution, following the Indian example. As it stands, it is quite likely that citizens remain inclined to perceive environmentally-deleterious activities as statutorily prohibited acts rather than morally-reprehensible criminal acts.

\subsection{Litigant support}

One of the central qualities of a rights-based approach to enforcement, be it in environmental protection or with respect to

44 See sec 243(k) of the Constitution.

45 Boyle (n 1 above) 8. 
citizens' enjoyment of other rights, is that it is predominantly based on a proactive party bringing, or threatening to bring, litigation against an offending party. ${ }^{46}$ Importantly, with respect to environmental rights, this often means that whether such rights are exercised or enjoyed and used as a complement to other enforcement efforts, often depends on parties who suffer harm, or wish to act in protection of the environment from a public interest basis, having the capacity to bring, or threaten to bring, environmental rights-based litigation. However, the difficulty that such an approach poses to citizens' actual exercise or enjoyment of environmental rights is that litigation is an expensive affair. Without the financial resources to bring litigation, it is difficult to bring, or threaten to bring, environmental rights-based litigation. In order to counteract this, it becomes important at the institutional level to ensure that measures are in place to assist litigants to meet the costs of litigation and, in this way, preclude economic barriers limiting the exercise and enjoyment of their environmental rights.

Certainly, under the new Zimbabwean constitutional dispensation, there has been an apparent effort made to try and ensure that litigants gain access to court. ${ }^{47}$ Most notably, this has been attempted through a turn to a broad approach to locus standi. To this end, section $85(1)$ of the Constitution provides access to court to persons acting in their own interests, on behalf of another person, as a group or class, in the public interest, and as an association acting in the interests of its members, alleging that any fundamental right in the Declaration of Rights has been infringed or is likely to be infringed.

Broadening locus standi in this manner is a laudable development considering that such a move has traditionally been shown to aid litigants in meeting litigation costs across various jurisdictions. ${ }^{48}$ This is because broadening locus standi allows deep-pocketed litigants, who are not necessarily the direct victims of some harmful act, to bring environmental rights-based litigation in protection of the environment. ${ }^{49}$ In addition, such deep-pocketed individuals now have room to financially assist those wishing to bring public interest litigation based on environmental rights.

It is worth noting, however, that broadening the pool of potential litigants does not necessarily mean deep-pocketed individuals will begin to bring environmental rights-based claims. This is particularly true of Zimbabwe where, even prior to the ongoing economic crisis, there have not been instances in which such deep-pocketed individuals have brought public interest litigation, or leant their

46 See, however, Boyle (n 1 above) 1-3.

47 Timoshenko ( $\mathrm{n} 3$ above) 127; Boyle (n 1 above) 10; A Hurrell \& B Kingsbury The international politics of the environment (1992) 3; JL Dunoff 'From green to global: Toward the transformation of international environmental law' (1995) 19 Harvard Environmental Law Review 282-283.

48 McGrath (n 7 above) 335-340.

49 Preston (n 18 above) 8-13; McGrath (n 7 above) 325-331. 
support to such litigation. In addition, broadening locus standi does little to assist the individual rights holder who wishes to pursue environmental rights-based litigation. In light of this, it becomes particularly important to consider that, beyond broadening the pool of potential litigants, little has been done at the institutional level to ensure that litigants receive financial support in bringing environmental rights-based claims to courts. As such, many of the deficiencies which attached to litigant support prior to the transition to constitutional environmental rights remain.

Certainly, with respect to the provision of fundamental rights in constitutions, most constitutions are best described as framework legislation. This is a reference to the fact that declarations of rights in constitutions typically contain basic fundamental rights provisions with the expectation that the legislature will subsequently craft more comprehensive legislation which gives effect to rights contained in the constitution. ${ }^{50}$ It may have been unreasonable, therefore, to have expected the Zimbabwean Constitution to make provision for litigant support in the Declaration of Rights. However, it was certainly not unreasonable to expect the drafters to include in the Constitution provisions asserting an obligation on the state or the legislature to put in place measures to ensure that citizens exercised their rights where they so wished and, as such, would enjoy the benefits these rights bestowed. ${ }^{51}$ Indeed, in light of the experience with environmental rights in Zimbabwean law, such a provision was necessary even if this obligation would have been qualified by the usual disclaimer based on the availability of resources.

This is certainly not a far-fetched proposal, considering that there was already an environmental law framework in place, established by the Environmental Management Act, which carried provisions that established funds for environmental protection and management. For instance, section 48 of the Environmental Management Act makes provision for an Environmental Fund which has already been established. To date, functions of the Fund have been limited to such endeavours as the standardisation of environmental management, financing the extension of environmental management services to

50 McGrath (n 7 above) 349-353.

51 Here, it is useful to bear in mind that the goal of most constitutions, codified, written or unwritten, is to attain constitutionalism. See $\mathrm{H}$ Barnett Constitutional and administrative law (2003) 9; M Ryan Unlocking constitutional and administrative law (2007) 13; AW Bradley \& KD Ewing Constitutional and administrative law (2007) 4-5. As such, there is no prescribed template for the form a Constitution should take. All that matters is that it facilitates the attainment of constitutionalism. This is arguably the reason why written constitutions assume different forms with provisions varying based on what the pursuit of constitutionalism requires in a particular jurisdiction. In light of this, and considering the context in which environmental rights were being included in the Constitution, it was reasonable to expect a more assertive obligation on the legislature to put in place measures to ensure that citizens exercised their rights where they so wished and, as such, would enjoy the benefits these rights bestowed. 
under-serviced areas, and facilitating, for the benefit of Zimbabwe, the transfer of environmental management services technology from foreign providers of such technology. ${ }^{52}$ It would not have been unreasonable, therefore, to extend the functions of the Fund to assisting litigants in bringing cases to court.

Such a proposal is also not far-fetched when one considers that the directive on the legislature to craft legislation to assist citizens in bringing rights-based litigation could have been the basis for the turn to laws containing measures to facilitate the abatement or removal of prohibitive costs, as has occurred in other jurisdictions. ${ }^{53}$ For instance, in Scotland, the step was taken to ensure that individuals or environmental pressure groups bringing environmental cases against public bodies would be able to apply for a protective expenses order, limiting their liability for the other side's costs to $£ 5000$. In addition, a cap has also been placed on public bodies' liability for the applicant's expenses. ${ }^{54}$

These are all realisable institutional measures which could have been adopted into Zimbabwean law at the time of formulating and drafting the 2013 Constitution through the inclusion of a provision directing the legislature to enact legislation facilitating citizens' enjoyment of their environmental rights in section 73 or in section 85 . That none of this was done means that there remains the possibility of litigants bearing the costs of litigation on their own. Indeed, as it stands, the possibility remains that citizens' full exercise or enjoyment of environmental rights enshrined in the Constitution will be restricted based on cost-related reasons.

\section{Conclusion}

Zimbabwean law has historically recognised the important role that environmental rights play within the environmental law regulatory framework. Despite this, there have been very limited efforts at the institutional level to ensure that citizens actually exercised and enjoyed their rights. If anything, institutional deficiencies and inadequacies culminated in Zimbabweans being unable to fully exercise or enjoy the benefits bestowed by their environmental rights.

Against this backdrop, the inclusion of environmental rights in section 73 of the 2013 Constitution stands as a momentous achievement. It is not often that environmental rights are accorded

52 See secs 52(a) - (j) of the Environmental Management Act.

53 McGrath (n 7 above) 335-340.

54 Scotland's Act of Sederunt (Rules of the Court of Session Amendment) (Protective Expenses Orders in Environmental Appeals and Judicial Reviews) 2013. 
constitutional importance. ${ }^{55}$ As such, including environmental rights in the Declaration of Rights of the Constitution affirms the country's recognition of the important role that environmental rights play in any environmental regulatory framework.

Importantly, while such a development merits some celebration, the Zimbabwean history with environmental rights has shown it to be true that, while the important role that environmental rights play in the regulatory framework has been recognised, there has been less emphasis placed on putting in place institutional measures to ensure that citizens actually exercise and enjoy these environmental rights. Importantly, under the pre-2013 environmental regulatory framework, the absence of these institutional measures as a complement to environmental rights compromised citizens' exercise or enjoyment of these environmental rights. It was reasonable to expect, therefore, based on this history, that with the coming into effect of constitutional environmental rights, a concerted effort would be made to ensure that the environmental rights in the Constitution would be complemented by adequate institutional measures to ensure citizens actually exercise and enjoy their environmental rights.

In conclusion, and based on an analysis of the present rights-based approach adopted as a complement to the Zimbabwean environmental regulatory framework, the preceding discussion has highlighted that, while the inclusion of the rights in the Constitution is a laudable development, the same institutional inadequacies which compromised citizens' exercise and enjoyment of their environmental rights prior to the Constitution remain. Certainly, there is still time to address these institutional inadequacies and facilitate citizens' exercise and enjoyment of their rights. However, such efforts would need to be measured and intricate. Considering that this could all have been addressed during the constitution-making process, the fact that this was not done stands as a significant and missed opportunity to address those institutional inadequacies which culminated in barriers to citizens' enjoyment of their environmental rights.

55 Boyle (n 8 above) 627; Boyle (n 1 above) 7; D Shelton 'A background paper for the World Health Organisation' 22 (2002) http://www.who.int/hhr/information/ en/Series_1\%20\%20Human_Rights_Health_Environmental\%20Protection_Shelton .pdf (accessed 29 May 2015). 